\title{
Representasi Identitas Generasi Milenial dalam Caption Instagram Aktor Sosial Generasi X
}

\section{Identity Representation of the Millennial Generation in the Instagram Caption of Generation X Social Actors}

\author{
Duma Sarah Adinda Silalahi*, \& Iwa Lukmana \\ Universitas Pendidikan Indonesia, Bandung, Jawa Barat, Indonesia \\ dumasilalahi19@upi.edu*
}

Naskah diterima tanggal 7/01/2021, direvisi akhir tanggal 24/04/2021, disetujui tanggal 30/04/2021

\begin{abstract}
Abstrak
Penelitian ini bertujuan untuk menelaah representasi identitas generasi milenial dalam caption Instagram aktor sosial generasi $X$. Penelitian ini mengaplikasikan Linguistik Sistemik Fungsional (LSF) yang digagas oleh M.A.K. Halliday \& Matthiessen (2014) sebagai kerangka ilmiah, terutama pengaplikasian konsep sistem transitivitas. Data berupa 10 caption Instagram yang berasal dari unggahan akun Instagram aktor sosial generasi X. Pengumpulan data menggunakan purposive sampling sehingga data yang dikumpulkan hanya yang sesuai dengan tujuan penelitian. Setiap caption dipisah berdasarkan klausa untuk mempermudah proses analisis transitivitas. Hasil penelitian ini mengungkapkan bahwa secara umum generasi milenial dikelompokkan sebagai anak muda yang memiliki jiwa entrepreneurship dan mampu memecahkan masalah. Mereka juga direpresentasikan sebagai agen perubahan dan generasi penerus yang cerdas dan kompetitif. Secara khusus, generasi milenial merupakan kelompok mahasiswa yang direpresentasikan sebagai generasi masa depan dan anak-anak yang kreatif. Identitas tersebut menunjukkan peran generasi milenial sebagai agent of change, social control, dan iron stock.
\end{abstract}

Kata kunci: Experiencial Meaning; Identitas; Instagram; Linguistik Sistemik Fungsional; milenial; sistem transitivitas.

\begin{abstract}
This study aims to examine the identity representation of the millennial generation in the Instagram caption of generation $X$ social actors. This research applies Linguistik Sistemik Fungsional (LSF) initiated by Halliday \& Matthiessen (2014) as a scientific framework, especially applying the concept of the transitivity system. Data in the form of 10 Instagram captions came from uploads of X-generation social actor Instagram accounts. The data was collected using purposive sampling so that the data collected was only by the research objectives. Each caption is separated by clause to simplify the transitivity analysis process. The results of this study reveal that in general, the millennial generation is grouped as young people who have an entrepreneurial spirit and can solve problems. They are also represented as agents of change and the next generation who are intelligent and competitive. In particular, the millennial generation comprises students who are represented as future generations and creative children. This identity shows the role of the millennial generation as agents of change, social control, and iron stock.
\end{abstract}

Keywords: Experiential meaning; identity; Instagram; millennial; Systemic Functional Linguistics; transitivity system. 


\section{PENDAHULUAN}

Generasi milenial menjadi topik yang banyak diperbincangkan saat ini. Terlebih jika berkaitan dengan kecanggihan teknologi. Generasi milenial dianggap sebagai digital native karena menguasai penggunaan komunikasi digital mulai dari Facebook, Twitter, Youtube, ataupun Instagram (Muhammad \& Anwary, 2019).

Meskipun dikuasai oleh generasi milenial, tidak sedikit pula generasi tua, yaitu generasi $\mathrm{X}$ atau bahkan generasi boomer, yang juga beradaptasi dengan media sosial. Dalam media sosial Instagram misalnya, pengguna bisa dengan mudah menemukan aktor sosial generasi $\mathrm{X}$ yang aktif sebagai pengguna Instagram.

Pengguna media sosial berusaha membuat konten yang sesuai dengan sudut pandang dan tujuan mereka (Machmiyah, 2019). Dengan menganalisis caption Instagram aktor sosial generasi $\mathrm{X}$, identitas generasi milenial dapat diungkap dengan menganalisis sistem transitivitas yang membentuk caption tersebut. Isu ini akan dieksplorasi dengan memperkenalkan pengertian generasi milenial, media sosial Instagram, metafungsi bahasa dalam kajian LSF, dan sistem transitivitas.

Istilah generasi milenial saat ini sedang menjadi istilah yang akrab terdengar dan menjadi isu yang banyak dibicarakan oleh orang-orang. Secara terminologi, kata milenial belum ditemukan dalam KBBI daring. Istilah ini pertama kali digunakan oleh William Strauss dan Neil Howe, ahli demografis, untuk kelompok anak yang terhubung dengan awal masuknya milenium baru, yaitu antara tahun 1980-1995 (Mansyur, 2018).

Pembagian kelompok demografis ini juga berlaku pada generasi $\mathrm{X}$, generasi yang lahir sebelum generasi milenial yaitu antara tahun 1965-1980. Generasi milenial identik dengan generasi muda yang menguasai teknologi (Mutia, 2017).

Tumbuh besar bersama dengan kecanggihan teknologi digital menjadi salah satu faktor yang membuat generasi ini berbeda dengan generasi sebelumnya, yaitu generasi $\mathrm{X}$ dan baby boomer, baik pada sifat, sikap, cara berfikir, dan cara berkomunikasi (Mutiaz,
2019). Penguasaan teknologi oleh generasi milenial juga ini terlihat dari jumlah pengguna media sosial.

Penggunaan media sosial menjadi salah satu parameter keakraban milenial dengan teknologi. Berbagai platform media tersedia mulai dari Facebook, YouTube, WhatsApp, Twitter, dan Instagram untuk membuat manusia terhubung satu dengan yang lainnya.

Data Reportal (2020) We Are Social pada Januari 2020, Instagram merupakan media sosial dengan pengguna terbanyak dalam urutan keempat. Penggunanya mencapai $63 \mathrm{jt}$ orang, dan $65,7 \%$ dari total populasinya adalah kelompok usia 18-34 tahun, yaitu generasi milenial, sementara pengguna Instagram dari generasi tua berjumlah sekitar $18 \%$ saja dari total populasi pengguna Instagram.

Salah satu daya tarik dari Instagram adalah fasilitas yang disediakan oleh platform ini untuk mengelola tampilan diri untuk publik melalui foto dan dilengkapi oleh keterangan foto atau caption. Sama halnya dengan generasi milenial, beberapa aktor sosial generasi $\mathrm{X}$ juga aktif menggunakan Instagram untuk tujuan-tujuan tertentu.

Beberapa diantara adalah Ridwan Kamil, Sandiaga Uno, Erick Thohir, Muhaimin Iskandar, Sri Mulyani, dan Ganjar Pranowo. Masing-masing aktor sosial tersebut merupakan aktor sosial generasi $\mathrm{X}$ dan memiliki latar belakang sebagai politisi. Unggahan Instagramnya menampilkan banyak hal, salah satunya tentang generasi milenial. Meskipun tidak bisa sepenuhnya sesuai dengan realitas, Pengguna media sosial berusaha membuat konten yang sesuai dengan sudut pandang dan tujuan mereka (Machmiyah, 2019).

Dapat disimpulkan bahwa generasi $\mathrm{X}$ akan mengunggah sesuatu tentang generasi milenial berdasarkan pengalaman mereka terhadap generasi milenial. Hal ini selaras dengan fungsi bahasa yang dibahas di dalam kajian LSF, yaitu untuk merepresentasikan ide atau gagasan yang ada dalam kognisi manusia ke dalam kata-kata atau disebut dengan experiencial meaning (Bakuuro, 2017).

Dalam pendekatan LSF, bahasa dapat membentuk tiga fungsi secara bersamaan yang 
disebut dengan metafungsi bahasa. Menurut Saragih (2007), metafungsi bahasa atau penciptaan makna yang secara bersamaan bukan merupakan suatu penggolongan dimana makna yang satu lebih kuat dari yang lainnya.

Masing-masing makna yang tercipta memiliki fungsi untuk menggambarkan (ideational meaning), mempertukarkan (interpersonal meaning) dan merangkai (textual meaning) pengalaman manusia. Ideational meaning mencakup kemampuan bahasa merepresentasikan pengalaman baik dari dalam diri maupun dari luar diri individu yang disebut experiential meaning dan memperlihatkan hubungan nalar antar pengalaman tersebut melalui logical meaning (Yuwana, 2019). Pengalaman manusia dapat disampaikan melalui bahasa karena bahasa memiliki komponen pembentuk makna pengalaman yang disebut dengan sistem transitivitas.

Sistem transitivitas merupakan leksikogramatika pembentuk makna pengalaman. Makna pengalaman yang terdapat dalam teks secara gramatikal dapat diketahui melalui sistem transitivitas yang merujuk pada representasi proses, partisipan, dan sirkumtansi (Alameda-Hernández, 2008).

Ketiga aspek ini tidak hanya pelabelan struktur klausa pada teks. Setiap aspek memiliki kontribusi dalam memberikan karakterisasi spesifik sebuah teks. Sistem transitivitas tertentu akan membentuk teks tertentu pula (Halliday \& Matthiessen, 2004).

Proses merupakan aspek pertama dan yang utama dalam sistem transitivitas. Karena pengalaman yang akan diekspresikan dapat membentuk makna yang berbeda tergantung pada tipe prosesnya (Matthiessen, 2021). Partisipan akan secara otomatis mengikuti jenis proses. Sama halnya dengan sirkumtansi jika diperlukan.

Penelitian ini bertujuan untuk menelaah realisasi identitas generasi milenial yang terdapat di dalam caption Instagram aktor sosial generasi X. Secara spesifik, penelitian ini akan menganalisis peran partisipan dalam teks berupa caption Instagram aktor sosial generasi $\mathrm{X}$.

Pendekatan Linguistik Sistemik Fungsional (LSF) yang ditemukan oleh
Halliday \& Matthiessen (2014) akan diaplikasikan untuk menjawab permasalahan yang diajukan di dalam penelitian ini.

Secara khusus, penelitian ini akan menganalisis sistem transitivitas yang terbentuk di dalam wacana Instagram aktor sosial generasi $\mathrm{X}$ yang membahas tentang generasi milenial atau yang diasosiasikan kepada generasi milenial. Konstruksi identitas generasi milenial dapat dilihat melalui peran partisipan (participant role) yang membentuk sebuah klausa berdasarkan proses yang diikutinya (Bangga, 2019).

Mengaplikasikan pendekatan SFL dalam penelitian ini dianggap sangat sesuai karena pendekatan ini sangat interpretatif untuk melihat bahasa sebagaimana bahasa digunakan.

\section{METODE PENELITIAN}

Penelitian ini menggunakan metode deskriptif kualitatif. Metode penelitian dapat dipahami sebagai kegiatan ilmiah yang bertahap. Penelitian deskriptif kualitatif merupakan kegiatan ilmiah yang bersifat natural dan interpretatif, dimana peneliti berusaha menguak suatu fenomena dan interaksi manusia secara natural dalam kondisi tertentu (Golafshani, 2003).

Penelitian ini hanya akan mendeskripsikan isu yang diangkat atau menjelaskan fenomena bahasa yang terjadi, tidak untuk menjelaskan hubungan sebab akibat atau korelasi suatu masalah atau peristiwa (Raco, 2010).

Dengan menerapkan teori Linguistik Sistemik Fungsional (LSF), data bahasa yang didapatkan akan diteliti berdasarkan sistem transitivitas yang membentuk teks tersebut. Teori LSF dianggap sangat sesuai untuk diterapkan dalam penelitian ini karena teori ini sangat interpretatif untuk melihat bahasa sebagaimana bahasa digunakan (Halliday \& Matthiessen, 2004).

Data yang digunakan dalam penelitian ini adalah caption Instagram. Caption Instagram merupakan keterangan foto yang diunggah di media sosial Instagram. Menurut Hurley (2019), caption tidak hanya sekedar keterangan foto, lebih dari itu, caption menjadi media perantara penggunanya untuk 
menkontruksi diri mereka yang tidak mudah untuk direalisasikan atau diinginkan di dunia offline. Terdapat 10 caption yang dianalisis untuk menjawab masalah penelitian ini. Masing-masing caption terdiri dari 4-13 klausa.

Masalah yang diangkat dalam penelitian ini adalah isu tentang representasi generasi milenial, maka data yang digunakan harus dipilih sesuai dengan kebutuhan penelitian. Data yang digunakan harus bersifat purposive, yaitu sesuai dengan tujuan penelitian, credible, dan information rich (Raco, 2010).

Caption Instagram yang dipilih adalah caption Instagram yang membahas tentang generasi milenial. Caption dipilih berdasarkan unggahan dari akun Instagram enam aktor sosial generasi $\mathrm{X}$ yang memiliki latar belakang politik. Mereka adalah Ridwan Kamil @ridwankamil, Sandiaga Uno@sandiuno, Ganjar Pranowo@ganjar_pranowo, Erick Thohir@erickthohir, Sri Mulyani @smindrawati dan Muhaimin Iskandar @ cakiminnow. Aktor sosial ini juga dipilih

\section{HASIL DAN PEMBAHASAN}

\subsection{Hasil}

Representasi identitas yang dikaji dalam penelitian ini menggunakan pendekatan Linguistik Sistemik Fungsional (LSF) yang berfokus pada makna pengalaman (experiencial meaning). Berdasarkan hasil analisis data ditemukan bahwa identitas generasi milenial yang direpresentasikan dalam caption Instagram aktor sosial generasi $\mathrm{X}$ secara umum dan secara khusus.

Secara umum generasi milenial dikelompokkan sebagai anak muda yang memiliki jiwa entrepreneurship dan mampu memecahkan masalah. Mereka juga direpresentasikan sebagai agen perubahan dan generasi penerus yang cerdas dan kompetitif. Secara khusus, generasi milenial merupakan kelompok mahasiswa yang direpresentasikan sebagai generasi masa depan dan anak-anak yang kreatif.

Identitas generasi milenial dalam unggahan Instagram aktor sosial generasi dapat diprediksi melalui pemilihan sistem transitivitas yang membentuk klausa dalam caption tersebut. Khususnya dalam proses relasional. Proses relasional merupakan proses dengan mempertimbangkan jumlah pengikut Instagramnya, keaktifan menggunakan Instagram, dan ketenarannya. Selain itu akun media sosial aktor sosial ini juga sudah diverifikasi oleh Instagram yang menandakan akun tersebut adalah akun Instagram asli dari aktor sosial.

Analisis data dilakukan dengan memisahkan caption berdasarkan satuan lingual terbesar yang dipilih, yaitu klausa. pemisahan ini dilakukan untuk mempermudah proses analisis sistem transitivitas. hasil dari proses analisis transitivitas akan menunjukkan kecenderungan proses dan partisipan yang muncul paling banyak dalam teks yang dianalisis. Berikut ini adalah contoh analisis transitivitas dalam caption Instagram aktos sosial generasi $\mathrm{X}$.

Tabel 1 Contoh analisis transitivitas caption Instagram Setiap anak harus memiliki jiwa entreprenuership muda

Carrier pr. Relational Attribute
Attributive

yang berfungsi untuk mendeskripsikan sifat atau identitas suatu entitas (Wachidah, 2010).

Hasil temuan berupa klausa-klausa yang terbentuk dari proses relational attributive dan proses relational identifying. Maka peran partisipan yang dapat mendeskripsikan identitas generasi milenial merupakan carrier, attribute, token dan value.

\subsection{Pembahasan}

Secara umum, generasi milenial dideskripsikan sebagai kelompok anak muda. Identitas mereka tergambar melalui atribut yang melekat dalam dirinya. Identitas generasi milenial direpresentasikan sebagai anak muda yang memiliki kemampuan menyelesaikan masalah seperti pada tabel 2.

Tabel 2. Caption Instagram @ridwankamil teks 6, klausa 3-4

\begin{tabular}{llll}
\hline jadilah & $\begin{array}{l}\text { pemuda } \\
\text { pemberi } \\
\text { solusi }\end{array}$ & $\begin{array}{l}\text { bukan } \\
\text { \{menjadi\} }\end{array}$ & $\begin{array}{l}\text { pemuda } \\
\text { pemaki- } \\
\text { maki }\end{array}$ \\
\hline $\begin{array}{l}\text { Pr. } \\
\text { Relational } \\
\text { attributive }\end{array}$ & Attribute & $\begin{array}{l}\text { Pr. } \\
\text { Relational } \\
\text { attributive }\end{array}$ & Attribute \\
\hline
\end{tabular}

Tabel 2 merupakan potongan caption Instagram@ridwankamil sebagai ucapan 
perayaan Sumpah Pemuda 2019. Tidak ditemukan carrier dalam tabel 2 karena klausa tersebut merupakan klausa imperatif.

Melalui konteks teks, dapat diketahui bahwa kalimat ini ditujukan kepada anak muda. Maka secara implisit, carrier dari contoh tabel 2 adalah pronomina 'kalian' yang merujuk kepada anak muda. Attribute yang menjelaskan anak muda adalah 'pemuda pemberi solusi'. Tabel 2 menjelaskan generasi milenial meskipun secara fisik masih muda, secara emosional generasi milenial dituntut untuk bisa menghadapi masalah secara dewasa, dengan menghadapi dan memberikan solusi bukan dengan marah-marah.

Representasi generasi milenial sebagai anak muda yang mampu menjadi pemecah masalah juga berkaitan dengan kepemilikan jiwa entrepreneurship seperti tabel 3.

Tabel 3. Caption Instagram @sandiuno teks 1, klausa 1

\begin{tabular}{lll}
$\begin{array}{l}\text { Setiap anak } \\
\text { muda }\end{array}$ & harus memiliki & $\begin{array}{l}\text { jiwa } \\
\text { entrepreneurship }\end{array}$ \\
Carrier & $\begin{array}{l}\text { pr. Relational } \\
\text { Attributive }\end{array}$ & Attribute \\
\hline
\end{tabular}

Proses relational yang ditemukan pada contoh tabel 3 adalah proses 'memiliki'. Memiliki merupakan proses relational attributive kategori possessive, yaitu proses ini menjelaskan hubungan kepemilikan antara carrier dan attribute. Ditemukan pula modulasi 'harus'. Dalam analisis makna interpersonal, modulasi digunakan sebagai penekanan agar lawan bicara melakukan atau melarang untuk melakukan sesuatu (Eggins, 2004). Atribut yang disematkan kepada anak muda adalah jiwa entrepreneurship. Entrepreneurship dalam Oxford learner's dictionaries adalah 'the activity of making money by starting or running businesses, especially when this involves taking financial risk'. Dalam bahasa Indonesia, kegiatan ini disebut dengan kewirausahaan. Dijelaskan bahwa kegiatan bisnis ini mencakup penanganan risiko keuangan. Sehingga dapat disimpulkan bahwa generasi milenial harus memiliki jiwa entrepreneurship untuk dapat menjadi problem solver dalam masalahmasalah keuangan.

Generasi milenial juga direpresentasikan sebagai generasi penerus yang berwawasan dan kompetitif.

Tabel 4. Caption Instagram @sandiuno teks 2, klausa

\begin{tabular}{|c|c|c|c|c|c|c|}
\hline $\begin{array}{l}\text { dibutuh } \\
\text { kan }\end{array}$ & $\begin{array}{l}\text { gener } \\
\text { asi } \\
\text { pener } \\
\text { us } \\
\text { bang } \\
\text { sa }\end{array}$ & $\begin{array}{l}\text { yang } \\
\text { memili } \\
\text { ki }\end{array}$ & $\begin{array}{l}\text { intelektu } \\
\text { alitas }\end{array}$ & $\begin{array}{l}\mathrm{da} \\
\mathrm{n}\end{array}$ & $\begin{array}{l}\text { berday } \\
\text { a saing }\end{array}$ & tinggi \\
\hline \multirow[t]{2}{*}{$\begin{array}{c}\text { Pr. } \\
\text { Mental }\end{array}$} & $\begin{array}{l}\text { Carri } \\
\text { er }\end{array}$ & $\begin{array}{l}\text { Pr. } \\
\text { Relatio } \\
\text { nal } \\
\text { attribu } \\
\text { tive }\end{array}$ & Attribute & & $\begin{array}{l}\text { Pr. } \\
\text { Relatio } \\
\text { nal } \\
\text { attribu } \\
\text { tive }+ \\
\text { Attribu } \\
\text { te }\end{array}$ & $\begin{array}{l}\text { Pr. } \\
\text { Relatio } \\
\text { nal } \\
\text { attribu } \\
\text { tive }+ \\
\text { Attribu } \\
\text { te }\end{array}$ \\
\hline & \multicolumn{6}{|c|}{ Phe } \\
\hline
\end{tabular}

Generasi penerus bangsa merujuk kepada generasi milenial. Dalam contoh tabel 4 terdapat proses yang sama dengan contoh tabel 3, yaitu proses memiliki. Attribute yang menjelaskan generasi penerus adalah kemampuan intelektualitas dan daya saing tinggi. Memiliki intelektualitas bukan hanya berkaitan dengan akademik, akan tetapi cerdas dalam berbagai aspek. Selain itu generasi penerus juga disebutkan harus memiliki daya saing tinggi. Hal ini merepresentasikan identitas generasi milenial sebagai generasi penerus yang kompetitif.

Generasi penerus juga direpresentasikan sebagai agen perubahan, seperti pada tabel 5.

Tabel 5. Caption Instagram @sandiuno teks 2, klausa

\begin{tabular}{|c|c|c|c|c|c|c|}
\hline $\begin{array}{l}\text { gener } \\
\text { asi } \\
\text { pener } \\
\text { us } \\
\text { inilah }\end{array}$ & $\begin{array}{l}\text { yang } \\
\text { nanti } \\
\text { nya }\end{array}$ & $\begin{array}{l}\text { akan } \\
\text { menjad } \\
\text { i }\end{array}$ & $\begin{array}{l}\text { agen } \\
\text { peruba } \\
\text { han }\end{array}$ & $\begin{array}{l}\text { ya } \\
\text { ng }\end{array}$ & $\begin{array}{l}\text { sangat } \\
\text { dibutuh } \\
\text { kan }\end{array}$ & $\begin{array}{l}\text { negeri } \\
\text { ini }\end{array}$ \\
\hline \multirow[t]{2}{*}{$\begin{array}{l}\text { Carri } \\
\text { er }\end{array}$} & \multirow{2}{*}{$\begin{array}{l}\text { Cir. } \\
\text { Exten } \\
t\end{array}$} & \multirow{2}{*}{$\begin{array}{l}\text { Pr. } \\
\text { Relatio } \\
\text { nal } \\
\text { attribu } \\
\text { tive }\end{array}$} & senser & & $\begin{array}{l}\text { Pr. } \\
\text { Mental }\end{array}$ & $\begin{array}{l}\text { phenome } \\
\text { non }\end{array}$ \\
\hline & & & Attribute & & & \\
\hline
\end{tabular}

Proses 'menjadi' termasuk kategori proses relational attributive intensive. Proses ini dapat terungkap melalui jangka waktu (Halliday \& Matthiessen, 2004). Dalam tabel 5 diperjelas dengan sirkumstansi extent yang menjelaskan durasi waktu yang tidak aktual, yaitu keterangan 'yang nantinya'. Dari penjelasan ini dapat disimpulkan bahwa identitas generasi milenial adalah sebagai agen perubahan untuk masa depan.

Secara khusus, generasi milenial merujuk kepada kelompok-kelompok tertentu. Dalam teks yang dianalisis, generasi milenial juga merujuk kepada mahasiswa. Identitas generasi 
milenial yang merujuk kepada mahasiswa direpresentasikan sebagai orang yang kreatif. Hal tersebut tergambar dalam tabel 6 .

Tabel 6. Caption Instagram @ganjarpranowo teks 3,

\begin{tabular}{|c|c|c|c|c|c|c|}
\hline $\begin{array}{l}\text { ja } \\
\text { di }\end{array}$ & $\begin{array}{l}\text { inila } \\
\mathrm{h}\end{array}$ & $\begin{array}{l}\text { adala } \\
\mathrm{h}\}\end{array}$ & $\begin{array}{l}\text { cara } \\
\text { belaja } \\
\mathrm{r} \\
\text { kekin } \\
\text { ian }\end{array}$ & $\begin{array}{l}\text { mahasisw } \\
\text { anya }\end{array}$ & $\begin{array}{l}\text { \{bersif } \\
\text { at\} }\end{array}$ & $\begin{array}{l}\text { inova } \\
\text { tif }\end{array}$ \\
\hline & $\begin{array}{l}\text { Carr } \\
\text { ier }\end{array}$ & $\begin{array}{l}\text { Pr. } \\
\text { Relati } \\
\text { onal } \\
\text { attribu } \\
\text { tive }\end{array}$ & $\begin{array}{l}\text { Attrib } \\
\text { ute }\end{array}$ & Carrier & $\begin{array}{l}\text { Pr. } \\
\text { Relati } \\
\text { onal } \\
\text { attribu } \\
\text { tive }\end{array}$ & $\begin{array}{l}\text { Attrib } \\
\text { ute }\end{array}$ \\
\hline
\end{tabular}

Pada tabel 6 terdapat 2 klausa yang terbentuk dari proses relational attributive. Klausa pertama menjelaskan tentang cara belajar kekinian, dan klausa kedua menjelaskan tentang mahasiswa. Mahasiswa dalam konteks situasi teks ini dapat diasosiasikan sebagai generasi milenial.

Terdapat kata ' $\{$ bersifat\}' yang terletak di dalam tanda kurung kurawal yang artinya proses tidak tertulis secara implisit namun dapat diketahui melalui konteks situasi teks. Attribute yang melekat pada 'mahasiswa' sebagai carrier adalah kata 'inovatif'. Inovatif dalam kbbi.web.id berarti bersifat pembaruan (kreasi baru). Sehingga dapat disimpulkan bahwa generasi milenial memiliki identitas sebagai orang yang kreatif.

Selain melalui proses relational attributive, identitas juga dapat terbentuk dari proses relational identifying. Dalam teks yang dianalisis, proses relational identifying hanya ditemukan untuk menggambarkan identitas milenial kelompok mahasiswa seperti tabel 7 .

Tabel 7. Caption Instagram @smindrawati teks 7,

\begin{tabular}{|c|c|c|c|c|c|c|}
\hline \multicolumn{7}{|c|}{ klausa 4} \\
\hline $\begin{array}{l}\text { merekal } \\
\text { ah }\end{array}$ & $\begin{array}{l}\text { \{adalah } \\
\}\end{array}$ & $\begin{array}{l}\text { genera } \\
\text { si } \\
\text { masa } \\
\text { depan }\end{array}$ & $\begin{array}{l}\text { yang } \\
\text { pedul } \\
\mathrm{i}\end{array}$ & $\begin{array}{l}\text { da } \\
n\end{array}$ & $\begin{array}{l}\text { menja } \\
\text { ga }\end{array}$ & $\begin{array}{l}\text { indones } \\
\text { ia }\end{array}$ \\
\hline \multirow[t]{2}{*}{ Token } & $\begin{array}{c}P r . \\
\text { Relation } \\
\text { al }\end{array}$ & Senser & $\begin{array}{c}\text { Pr. } \\
\text { Ment } \\
\text { al }\end{array}$ & & $\begin{array}{c}P r . \\
\text { Materi } \\
\text { al }\end{array}$ & Goal \\
\hline & $\begin{array}{c}\text { identifyi } \\
n g\end{array}$ & \multicolumn{5}{|c|}{ Value } \\
\hline
\end{tabular}

Fungsi dari proses relational identifying adalah sebagai proses yang mendefinisikan satu entitas dengan entitas lain secara keseluruhan didefinisikan secara utuh adalah token 'mereka'. Terdapat partikel 'lah' yang menekankan peran kata 'mereka'. Verbal yang berada di posisi proses relational identifying dilesapkan, akan tetapi dapat diketahui dengan mencocokkan klausa tersebut dengan konteks situasi teks. Kata 'adalah' dipilih karena kata tersebut merupakan proses relational identifying yang paling umum dan paling sesuai untuk mendefinisikan value dalam tabel 7.

Generasi milenial dikategorikan sebagai individu yang memiliki elemen yang melekat pada dirinya, yaitu generasi masa depan. Adanya value 'generasi masa depan' menandakan bahwa identitas ini tidak dapat dipisahkan dari individu tersebut (Halliday \& Matthiessen, 2014).

Sama halnya dengan generasi milenial secara umum, generasi milenial dari kelompok mahasiswa juga digambarkan sebagai anak muda yang berwawasan luas. Identitas ini terbentuk melalui klausa identifying, seperti contoh di bawah ini.

Tabel 8. Caption Instagram @ smindrawati teks 7,

\begin{tabular}{|c|c|c|c|c|c|}
\hline \multicolumn{6}{|c|}{ klausa 2} \\
\hline $\begin{array}{l}\text { merek } \\
\mathrm{a}\end{array}$ & $\{$ adalah\} & $\begin{array}{l}\text { mahasis } \\
\text { wa }\end{array}$ & $\begin{array}{l}\text { yan } \\
\text { g }\end{array}$ & $\begin{array}{l}\text { memaha } \\
\text { mi }\end{array}$ & $\begin{array}{l}\text { banyak } \\
\text { dimensi }\end{array}$ \\
\hline \multirow[t]{2}{*}{ Token } & \multirow{2}{*}{$\begin{array}{l}\text { Pr. } \\
\text { Relation } \\
\text { al } \\
\text { identifyi } \\
\text { ng }\end{array}$} & Senser & & $\begin{array}{l}\text { Pr. } \\
\text { Mental }\end{array}$ & $\begin{array}{l}\text { Phenomen } \\
\text { on }\end{array}$ \\
\hline & & Value & & & \\
\hline
\end{tabular}

Value pada tabel 8 adalah 'mahasiswa'. Terdapat klausa adjektif yang menjadi keterangan sifat 'mahasiswa'. Memahami banyak dimensi dapat diartikan sebagai berwawasan, yaitu tidak hanya menguasai satu bidang tertentu. Jadi identitas generasi milenial bukan hanya sekedar mahasiswa, akan tetapi mahasiswa yang berwawasan dan menguasai berbagai bidang.

\section{KESIMPULAN}

Penelitian ini telah membahas realisasi identitas generasi milenial dalam caption Instagram aktor sosial generasi $X$. Sejauh pembahasan yang dipaparkan di atas, generasi milenial direpresentasikan secara positif. Generasi milenial identik dengan insan muda, generasi muda, dan generasi penerus.

Melalui penggunaan proses relational, identitas generasi milenial terbentuk berdasarkan atribut yang melekat pada generasi milenial sebagai carrier, juga value yang melekat pada token. Secara umum generasi milenial dikelompokkan sebagai 
anak muda yang memiliki jiwa entrepreneurship dan mampu memecahkan masalah.

Mereka juga direpresentasikan sebagai agen perubahan dan generasi penerus yang cerdas dan kompetitif. Secara khusus, generasi milenial merupakan kelompok mahasiswa yang direpresentasikan sebagai generasi masa depan dan anak-anak yang kreatif.

Identitas generasi milenial yang terungkap melalui analisis sistem transitivitas sesuai dengan peran mereka sebagai anak muda di era globalisasi, yaitu sebagai agent of change, social control, dan iron stock (Karisma et al., 2020). 


\section{DAFTAR PUSTAKA}

Alameda-Hernández, Á. (2008). SFL and CDA: Contributions of the Analysis of the Transitivity System in the Study of the Discursive Construction of National Identity. The Linguistics Journal, 160-175.

Bakuuro, J. (2017). Demystifying Halliday's Metafunctions of Language. International Journal of Language and Literature, 5(2), 211-217.

Bangga, L. A. (2019). Mengurai dan menyelaraskan identitas lewat pahlawan wanita: sebuah tinjauan semantik wacana dan lexico grammar. Seminar Internasional Kebahasaan. Jakarta: Pusat Pengembangan Strategi dan Diplomasi Kebahasaan.

Data Reportal. (2020). Digital 2020: Indonesia. Retrieved from https://atareportal.com/reports/digital-2020indonesia

Eggins, S. (2004). An Introduction To Systemic Functional Linguistics. New York: continuum.

Golafshani, N. (2003). Understanding Reliability and Validity in Qualitative Research. The Qualitative Report, 8(4), 597-606.

Halliday, M., \& Matthiessen, C. (2004). An Introduction to Functional Grammar: Third Edition. London: Hodder Arnold.

Halliday, M., \& Matthiessen, C. (2014). Halliday's Introduction to Functional Grammar Fourth Edition. New York: Routledge.

Hurley, Z. (2019). Imagined Affordances of Instagram and the Fantastical Authenticity of Female Gulf-Arab Social Media Influencers. SAGE, 1-16.

Karisma, D., Mujiwati, E. S., \& Mukmin, B. A. (2020). Peran Mahasiswa Milenial Dalam Era Revolusi Industri Untuk Indonesia Maju. Literasi Dalam Pendidikan di Era Digital Untuk Generasi Milenial. PROCEEDING. Literasi Dalam Pendidikan di Era Digital Untuk Generasi Milenial, 163-170.

Machmiyah, S. (2019, Juni). Self Representation in Social Media. Informasi, 49(1), 5.

Mansyur, U. (2018). Belajar Memahami Bahasa Generasi Milenial. https://doi.org/10.31227/osf.io/sxhp8

Matthiessen, C., \& Halliday, M. (2021). Systemic Functional Grammar: A First Step Into The Theory. Retrieved from https://www.researchgate.net/publication/265398862

Mutia, T. (2017). Generasi Milenial, Instagram dan Dramaturgi: Suatu Fenomena dalam Pengelolaan Kesan Ditinjau dari Perspektif Komunikasi Islam. Jurnal An-Nida', 41(2), 240-252.

Mutiaz, I. R. (2019). Konstruksi Realitas Simbolik Generasi Milenial Melalui Tema Fantasi Selebgram Di Media Sosial. Jurnal Sosioteknologi, Vol. 18(1), 113-130.

Muhammad, R. U., \& Anwary, A. (2019). Archieve media promotion for collective memory safety on digital natives generations. Record and Library Journal, 5(1), 50 - 61.

Raco, J. (2010). Metode Penelitian Kualitatif: Jenis, Karakteristik dan Keunggulannya. Jakarta: PT. Grasindo.

Saragih, A. (2007). Fungsi Tekstual Dalam Wacana. Medan: Balai Bahasa Medan.

Wachidah, S. (2010). Tipe Proses dalam Berbagai Teks dalam Koran serta Pengungkapannya dalam Kelas Kata Verba Bahasa Indonesia. Linguistik Indonesia, 201.

Yuwana, R. Y. (2019). Strategi Penciptaan Materi Humor: Analisis Transitivitas. Leksema, 4(1), 1-10. 